\title{
Taxation and Marriage: A Reappraisal
}

\author{
YAIR LISTOKIN*
}

\section{INTRODUCTION}

Marriage taxation presents a "trilemma": An income tax cannot simultaneously maintain progressive marginal tax rates, an equal tax burden for all married couples with identical incomes ("couples equity"), and neutrality with respect to the tax burden of married versus unmarried couples ("marriage neutrality").

In both academic debate and historical experience, progressive marginal income tax rates have been considered inviolable. Instead, debate and experience see-saw between forgoing couples equity or marriage neutrality. ${ }^{1}$ Proponents of couples equity, implemented by the joint filing system in place since 1948, argue that household income sharing justifies taxing married couples as a single unit. ${ }^{2}$ And if we are comparing units of taxation with identical incomes, tax equity prescribes that these units should be taxed identically. Proponents of marriage neutrality, by contrast, contest the notion that married couples are a single unit and abhor the marriage penalties and marriage bonuses that follow from a progressive income tax with couples equity. These scholars advocate individual filing. Everyone, married or single, should pay tax on their own income, regardless of their marital status, as they did from the advent of the income tax until 1948. ${ }^{3}$ With the exception of one paper focusing on the intersection of tax law with property and family law, ${ }^{4}$ scholars insist that we abandon either (or both) couples equity and/or marriage neutrality.

In this Article, I assume that the principles of couples equity and marriage neutrality both have merit. Alternatively, I assume that the

* Professor of Law, Yale Law School. I thank Michael Graetz, Louis Kaplow, Al Klevorick, Alex Raskolnikov, and seminar participants at Columbia Law School, Harvard Law School, University of Maryland Law School, and NYU Law School for many helpful comments. All errors are my own.

1 See Edward McCaffery, Taxing Women 23-26 (1997), and Lawrence Zelenak, Doing Something About Marriage Penalties: A Guide for the Perplexed, 54 Tax L. Rev. 1, 17-19 (2000), for a review of this literature.

2 See, e.g., Michael J. McIntyre \& Oliver Oldman, Taxation of the Family in a Comprehensive and Simplified Income Tax, 90 Harv. L. Rev. 1572, 1590 (1977).

${ }^{3}$ See, e.g., Lily Kahng, One Is the Loneliest Number: The Single Taxpayer in a Joint Return World, 61 Hastings L.J. 651, 684-85 (2010).

4 Henry E. Smith, Intermediate Filing in Household Taxation, 72 S. Cal. L. Rev. 145, 240-44 (1998). 
principles proxy for some more fundamental principles that result in an analogous trilemma. I also assume that the costs of deviations from either principle are convex; large deviations from either principle are disproportionately distasteful relative to small deviations. ${ }^{5}$

Under these conditions, the best schedule for the taxation of marriage maintains neither perfect couples equity nor perfect marriage neutrality. Instead, the optimal marriage taxation regime violates both couples equity and marriage neutrality, but to a smaller degree than previous and existing marriage taxation systems. Under my assumptions, violating two principles a little is better than violating one principle a lot.

The marriage taxation framework presented here offers a number of advantages. It transforms the debate regarding couples equity and marriage neutrality into one of degree rather than kind. Couples equity and marriage neutrality are merely two extremes along a spectrum. Indeed, the Code already contains several provisions that implicitly move the Code away from a pure couples equity system to a system that maintains neither couples equity nor marriage neutrality. ${ }^{6}$ Finally, my framework enables me to bring the third leg of the trilemma-progressive marginal tax rates-back into the discussion. Progressivity, without being discarded, may be reduced to lessen deviations from couples equity, marriage neutrality, or both.

\section{The Taxation of Marriage: Theory and Practice}

Edwin Cohen, former Assistant Secretary of the Treasury for Tax Policy, offered the following widely cited proof of the trilemma posed by the simultaneous desire to have progressive marginal tax rates, couples equity, and marriage neutrality. ${ }^{7}$

Assume there are four people, $A, B, C$, and $D . A$ and $B$ each make $\$ 10,000, C$ makes $\$ 0$, and $D$ makes $\$ 20,000$. The taxes owed by individual $A$ are denoted by $T(A)$, and the individual tax rates are $10 \%$ on the first $\$ 10,000$ in income and $25 \%$ on income in excess of $\$ 10,000$.) Progressive marginal tax rates imply that the tax on $C$ and $D$, as individuals, is greater than the combined tax on $A$ and $B$.

$$
T(C)+T(D)>T(A)+T(B)
$$

5 For discussion of this assumption, see Part III.

6 See Zelenak, note 1, at 4-8.

7 Tax Treatment of Single Persons and Married Persons Where Both Spouses Are Working: Hearings Before the H. Comm. on Ways and Means, 92d Cong. 78-79 (1972) (statement of Edwin S. Cohen, Ass't Sec'y for Tax Pol'y); see Michael J. Graetz \& Deborah H. Schenk, Federal Income Taxation, Principles and Policies 451-52 (7th ed. 2013) (citing Cohen testimony). 
Suppose that $A$ and $B(A B)$ and $C$ and $D(C D)$ get married. Marriage neutrality requires that each couple pay the same amount of income tax as they paid when single.

$$
T(A B)=T(A)+T(B)
$$

and

$$
T(C D)=T(C)+T(D)
$$

Couples equity requires that the income tax paid by both couples must be equal.

$$
T(A B)=T(C D)
$$

There is a contradiction. Replacing the right hand side of (I) with its value from (II) and replacing the left hand side of (I) with its value from (III) implies that $T(C D)>T(A B)$.

This contradicts (IV), so the conditions are incompatible. A numerical demonstration of the incompatibility is available in column (4) of Table 1.

\begin{tabular}{|c|c|c|c|c|c|c|}
\hline $\begin{array}{l}\text { Taxpayer } \\
\text { (Income) }\end{array}$ & $\begin{array}{l}\text { Tax if } \\
\text { Single }\end{array}$ & $\begin{array}{l}\text { Married } \\
\text { Individual Filing } \\
\text { (Marriage } \\
\text { Neutrality) } \\
\\
\quad(2)\end{array}$ & $\begin{array}{l}\text { Married Joint } \\
\text { Filing (Couples } \\
\text { Equity), 1948- } \\
\text { 1969 Regime } \\
\qquad \text { (3a) }\end{array}$ & $\begin{array}{l}\text { Married Joint } \\
\text { Filing (Couples } \\
\text { Equity), 1969- } \\
\text { 2014 Regime } \\
\qquad \text { (3b) }\end{array}$ & $\begin{array}{l}\text { Marriage } \\
\text { Neutrality and } \\
\text { Couples Equity } \\
\text { (4) }\end{array}$ & $\begin{array}{l}\text { Violation of } \\
\text { Both Couples } \\
\text { Equity and } \\
\text { Marriage } \\
\text { Neutrality } \\
\quad \text { (5) }\end{array}$ \\
\hline $\begin{array}{c}\text { A } \\
(\$ 10,000)\end{array}$ & $\$ 1000$ & $\begin{array}{l}\$ 2000 \\
\text { (No change in } \\
\text { tax on } \\
\text { marriage) }\end{array}$ & $\begin{array}{l}\$ 2000 \\
\text { (Same as CD) }\end{array}$ & $\begin{array}{l}\$ 2150 \\
\text { (Same as CD) }\end{array}$ & \multirow{4}{*}{$\begin{array}{l}\text { Impossible } \\
\text { (AB is different } \\
\text { from CD in col. } \\
\text { (2) due to the } \\
\text { progressivity of } \\
\text { the tax } \\
\text { schedule, but } \\
\text { AB is the same } \\
\text { as CD in cols. } \\
\text { (3a) and (3b).) }\end{array}$} & \multirow[t]{2}{*}{$\begin{array}{l}\$ 2500 \\
\text { (Greater than } \\
\text { individual filing } \\
\text { but less than } \\
\text { CD) }\end{array}$} \\
\hline $\begin{array}{c}\text { B } \\
(\$ 10,000)\end{array}$ & $\$ 1000$ & & & & & \\
\hline $\begin{array}{c}\mathrm{C} \\
(\$ 0)\end{array}$ & $\$ 0$ & \multirow[t]{2}{*}{$\begin{array}{l}\$ 3500 \\
\text { (No change in } \\
\text { tax on } \\
\text { marriage) }\end{array}$} & \multirow[t]{2}{*}{$\begin{array}{l}\$ 2000 \\
\text { (Same as AB) }\end{array}$} & \multirow[t]{2}{*}{$\begin{array}{l}\$ 2150 \\
\text { (Same as } \mathrm{AB} \text { ) }\end{array}$} & & \multirow[t]{2}{*}{$\begin{array}{l}\$ 3000 \\
\text { (Less than } \\
\text { individual filing } \\
\text { but more than } \\
\text { AB) }\end{array}$} \\
\hline $\begin{array}{c}\text { D } \\
(\$ 20,000)\end{array}$ & $\begin{array}{c}\$ 3500= \\
\$ 1000 \\
+2500\end{array}$ & & & & & \\
\hline
\end{tabular}

TABLE 1

The Marriage Trilemma

Table Description: For individual filing, columns (1) and (2), akin to $\S 1$ (c) filing, reflect a $10 \%$ marginal rate on the first $\$ 10,000$ of income and a $25 \%$ marginal rate on income in excess of $\$ 10,000$. Column (2) presents total taxes paid by the couple. For married joint filing, akin to $\S 1$ (a) from 1948 to 1969 , column (3a) reflects a $10 \%$ 
marginal rate on the first $\$ 20,000$ of income and a $25 \%$ marginal rate on income in excess of $\$ 20,000$. For married joint filing, akin to $\S 1$ (a) from 1969 to the present, column (3b) applies a 10\% marginal rate on the first $\$ 19,000$ of income and a $25 \%$ marginal rate on income in excess of $\$ 19,000$. Column (4) demonstrates that simultaneous progressivity, marriage neutrality, and couple equity is impossible. Column (5) presents a hypothetical marriage taxation schedule consistent with the policy recommendations of this Article that can be achieved in many different ways.

What to do? From 1948 through the present day, the Code has prioritized progressive marginal tax rates and couples equity, as in column (3) of Table $1 .^{8}$ This choice has several implications. It creates marriage penalties and bonuses. If couples $A B$ and $C D$ are to pay the same amount in taxes, then one or both couples will pay a different amount than if they had remained single and filed individually. In Table 1, column (3a), a tax of $\$ 2000$ on married couples filing jointly gives a marriage bonus to $C D$ (who would pay a combined $\$ 3500$ if they remained single) and neutrality to $A B$ (who would pay a combined $\$ 2000$ if they remained single). This was the tax rate under $\S 1$ (a) from 1948 to 1969 . A tax between $\$ 2000$ and $\$ 3500$ imposes a marriage penalty on $A B$ and a bonus on $C D$. This characterizes today's $\$ 1$ (a) filing schedule.

Choosing progressive rates and couples equity imposes high marginal tax rates on secondary earners. If $C$ in couple $C D$ takes $D$ 's income as given, then $C$ 's first dollar of income will be taxed at the same rate as $D$ 's last dollar of income. This would not be the case if $C$ were single, in which case $C$ (who has no income) would be taxed at the lowest marginal rate. ${ }^{9}$

Critics of joint filing argue that couples equity is not a compelling principle for structuring taxation of marriage. They claim that married couples with identical incomes are not necessarily equal from a tax perspective. Two-earner married couples, such as $A B$, may have higher expenses and lower imputed income than single-earner mar-

8 The Code achieves this by giving married couples the choice of filing jointly under $\S 1$ (a) or as a married individual filing separately under $\S 1$ (d). Joint filing under $\S 1$ (a) has a progressive rate structure and taxes married couples based on joint income, implementing couples equity. Section 1(d) allows for separate filing by each member of a married couple, but the rates and brackets of $\S 1$ (d) are so unfavorable that nearly all married couples pay less tax by filing under the $\S 1$ (a) schedule. Single individuals follow the schedule of $\S 1(\mathrm{~b})$ or $\S 1(\mathrm{c})$. The distinction between $\S 1(\mathrm{~b})$ (for heads of households) and $\S 1$ (c) (for unmarried individuals who are not heads of households as described in $\S 2$ (b)) is relevant only for unmarried couples with children, which is beyond the scope of this discussion. See McCaffery, note 1 , at 16.

9 See McCaffery, note 1, at 19-21. 
ried couples like $C D$, and should be taxed differently. ${ }^{10}$ In addition, joint filing imposes high marginal rates of tax on potential second earners such as $C .{ }^{11}$ High rates on secondary earners are likely inefficient, as secondary earners' labor decisions are much more sensitive to taxes than primary earners' labor decisions. ${ }^{12}$ Moreover, high tax rates on secondary earners reinforce stereotyped gender roles, providing a financial incentive for one member of a couple-typically, a woman-to stay at home. ${ }^{13}$

The undesirable properties associated with maintaining couples equity have led many commentators to prefer individual filing for married couples as well as singles, which was the structure of the Code from its inception through $1948 .{ }^{14}$ Marriage neutrality implemented through individual filing ameliorates or eliminates many of the failings associated with adherence to couples equity.

Proponents of couples equity relative to marriage neutrality muster several counterarguments. The U.S. income tax system measures ability-to-pay taxes by income. As a result, if married couples are an economic unit, then there is a presumptive case that they should pay the same tax if they have the same income. ${ }^{15}$ While it is true that couples with the same income are not identical, with some having more imputed income and others less (among other things), this is equally true of singles. Some single earners earn their income working long hours at a difficult job. Others earn the same income working fewer hours at a more pleasant job. But an income tax taxes both singles the same. Some of the arguments against couples equity are therefore really criticisms of taxation of income more generally.

Joint filing, which implements couples equity, is appropriate if ability to pay is properly measured by the collective income of a married couple rather than individual income. In a widely cited article on joint filing that supports the continuation of joint filing and couples equity, Boris Bittker reported the following position on the issue:

10 See id. at 23-28. In a single-earner marriage, the nonworking spouse may have significant imputed income from self-provided services such as childcare. See Zelenak, note 1, at 17 n.77.

11 See McCaffery, note 1 , at 19.

12 See Johnathan Gruber \& Emmanuel Saez, The Elasticity of Taxable Income: Evidence and Implications, $84 \mathrm{~J}$. Pub. Econ. 1, 4 (2002).

13 See McCaffery, note 1, at 20-23.

14 See id. at 5. Recent articles making this argument include James M. Puckett, Rethinking Tax Priorities: Marriage Neutrality, Children, and Contemporary Families, 78 U. Cin. L. Rev. 1409, 1434-35 (2010); Kahng, note 5, at 681-84.

15 See Boris I. Bittker, Federal Income Taxation and the Family, 27 Stan. L. Rev. 1389, 1431-33 (1975); McIntyre, note 2, at 1592-99. For a more recent defense of joint filing with a different definition of a marriage penalty, see Robert S. McIntyre \& Michael J. McIntyre, Fixing the "Marriage Penalty" Problem, 33 Val. U. L. Rev. 907 (1999). 
[A]s soon as a marriage is contracted, it is the continued income and financial position of the family which is ordinarily of primary concern, not the income and financial position of the individual members. Thus, the married couple itself adopts the economic concept of the family as the income unit from the outset. . . I It is probably even more true that the newly formed family acts as a financial unit in making its expenditures. ${ }^{16}$

Bittker concludes that couples equity has been "a dominant theme of tax theory for at least 50 years."17 The position adopted by Bittker is likely overstated. Married couples function as economic units for some purposes but not for others. The distribution of earnings within a married couple is not irrelevant, as it would be if a married couple is truly an undifferentiated economic unit. ${ }^{18} \mathrm{But}$ it is also true that the earnings of a spouse are not irrelevant. An individual with no income is considerably better off if their spouse earns a high income than if their spouse earns little. Bittker's position may be exaggerated, but it is not without a kernel of merit.

Bittker and other proponents of joint filing also observe that mandatory individual filing for married couples introduces incomeshifting incentives. ${ }^{19}$ Higher-earning spouses will attempt to shift income to the lower-earning spouse to lower the couples' aggregate tax burden. ${ }^{20}$ Indeed, the impossibility of joint filing before 1948 led to complicated alterations to state property law in an effort to facilitate income shifting. ${ }^{21}$ Joint filing eliminates the incentive to engage in specious transactions or otherwise undesirable legal changes in an attempt to minimize the total tax liability of a married couple. Joint

16 Bittker, note 15, at 1393 (quoting Report of the Royal Commission on Taxation 122-24 (1966) (Carter Commission)).

17 Id. at 1396. Bittker's position is truer today than when Bittker wrote in 1975. As of 2014 , couples equity has been the bedrock of income taxation of marriage for over sixtyfive years.

18 For evidence that household allocations respond to sources of income, see, e.g., $M$. Browning \& P.A. Chiappori, Efficient Intra-Household Allocations: A General Characterization and Empirical Tests, 66 Econometrica 1242, passim (1998) (citing additional authorities); Esther Duflo \& Christopher Udry, Intrahousehold Resource Allocation in Cote d'Ivoire: Social Norms, Separate Accounts and Consumption Choices (Nat'l Bureau Econ. Research, Working Paper No. 10498, 2004) (finding that household spending in Cote d'Ivoire responds differentially to shocks to female versus male earnings).

19 See Bittker, note 15, at 1394-96.

20 See id. at 1400-03.

21 Poe v. Seaborn, 282 U.S. 101 (1930), allowed couples to split income in community property states but not in common law property states. This ruling led some states to devise community property regimes to enable married couples to take advantage of income splitting. For a discussion, see McCaffery, note 1, at 46-49. 
filing also obviates the need to allocate income from communal property to one spouse or the other, an unavoidably byzantine process.

Both marriage neutrality and couples equity contain elements of two more fundamental goals of an income tax-equity and efficiency. A system of marriage taxation that is marriage neutral does not alter incentives to marry, enhancing efficiency. Marriage neutrality also ensures that labor/leisure trade-offs are unaffected by the system of marriage taxation. Marriage neutrality also embeds the equitable principle that marriage should not change someone's tax liability.

Couples equity eliminates the incentive for specious transactions between spouses, thereby enhancing efficiency. Couples equity also stands in for the equitable assertion that income tax obligations should be based on ability to pay, as measured by income. Ability to pay depends upon the total income of the economic unit and the relevant sharing rule for the economic unit. Any economic unit with perfect resource-sharing should be taxed as a single unit. Unfortunately, the taxing authority is not privy to the sharing rules of various economic units. Instead, the taxing authority must use some objective indicator of economic sharing. Marriage is one such indicator. ${ }^{22}$ Family law, for example, prescribes comprehensive sharing rules for property owned by married couples, indicating that married couples have agreed to become an economic unit to a greater degree than otherwise similar unmarried couples. ${ }^{23}$ Marriage also has an important social resonance that indicates a degree of shared economic life and general commitment. The ongoing struggle over same-sex marriage is a modern indicator of the salience attributed to "marriage," suggesting that marriage is correlated with behavioral patterns such as economic sharing. Because both marriage neutrality and couples equity contain elements of efficiency and equity, the conflict between marriage neutrality and couples equity cannot be viewed as a simple efficiency/ equity trade-off.

22 See Bittker, note 15, at 1392-99.

23 See, e.g., Smith, note 4 , at $234-40$ (considering the suitability of various marital property regimes' sharing rules as a basis for allocating taxable income). Henry Smith focuses on this interaction between property law and tax to propose his creative "intermediate filing" system for marriage taxation. See id. at 151-53. In some limited circumstances intermediate filing produces a marriage taxation regime that adheres to the approach developed here. See id. at 184 (describing intermediate filing, under which spouses' elective income allocation could produce a tax result coinciding with that produced under the present proposal). As currently proposed, however, intermediate filing often does not adhere to the principles developed here. See, e.g., id. at 147-53 (describing the trilemma and then presenting intermediate filing as a "third way" between achieving couples neutrality through joint filing and marriage neutrality through individual filing). This deviation is unsurprising, as Smith does not attempt to provide a general framework for taxation of marriage, instead focusing on the property law/tax law tension, under joint filing, see id. at $211-18$. 
This Article avoids adjudicating between couples equity and marriage neutrality as goals for the taxation of marriage. On balance, couples equity is a desirable property for an income tax. So is marriage neutrality. Different scholars may feel differently about the relative desirability of each principle but should not deny that the other side makes forceful arguments.

Instead of insisting on couples equity or marriage neutrality as absolute principles, I hope to move past this "battle of the neutralities." ${ }^{24}$ (Couples equity is sometimes termed couples neutrality. ${ }^{25}$ ) I accept both couples equality and marriage neutrality as worthwhile principles and seek to characterize good policy from this baseline.

In the next Part, I offer a general framework for evaluating any formula for the taxation of marriage. The model of taxation of marriage presented below begins from the simple premise that couples equity, marriage neutrality, and progressivity are worthwhile, if incompatible, goals. While there are no magic bullets to resolve the trilemma, the framework offers a more systematic way of studying the taxation of marriage within the trilemma's constraints.

\section{Trading Off Principles in the Taxation of Marriage}

My model (described in this Part and presented in the Appendix) assumes that both marriage neutrality and couples equity are valid objectives for the taxation of marriage. (Progressivity is introduced below.) The model allows for different weightings of the two objectives. Proponents of individual filing are likely to put a greater weight on marriage neutrality; joint filing advocates will emphasize couples equity. The purpose of this modeling exercise is not to forestall these debates, but rather to develop a common framework for them and to dampen the debates' "all or nothing" quality. ${ }^{26}$ Even if one finds the arguments favoring marriage neutrality more persuasive than the arguments favoring couples equity, this does not mean that couples equity is not a worthwhile goal.

\section{A. Assumptions of the Framework}

I assume that violations of couples equity and marriage neutrality grow increasingly distasteful as deviations increase in scale. (In math-

24 See Edward J. McCaffery, Taxation and the Family: A Fresh Look at Gender Biases in the Code, 40 UCLA L. Rev. 983, 986 (1993).

25 See, e.g., Smith, note 4, at 147.

26 Compare, e.g., McIntyre \& Oldman, note 2, at 1590, with, e.g., Pamela B. Gann, Abandoning Marital Status as a Factor in Allocating Income Tax Burdens, 59 Tex. L. Rev. 1, 2 (1990). 
ematical terms, the costs of deviations are convex.) A pragmatic policymaker or social planner desiring marriage neutrality, other things equal, is bothered relatively little by a difference in taxation of $\$ 100$ caused by marriage. An additional $\$ 100$ difference in taxation caused by marriage troubles the policymaker more than the first $\$ 100$, as the violation of marriage neutrality grows more egregious. The policymaker takes a similar view towards violations of couples equity. ${ }^{27}$

The assumption that costs of deviations from marriage neutrality and couples equity are convex is reasonable but debatable. An absolutist with lexical preferences with respect to marriage neutrality or couples equity may assert that any deviation from principle is unacceptable. Relatedly, there may be some fixed cost associated with deviating from one principle. If this is the case, then there are local nonconvexities around absolute adherence to one principle or the other. Alternatively, the costs of deviations from principle may be constant. In this case, one chooses a preferred principle (couples equity or marriage neutrality) and follows it to its limit, and then worries about satisfying the other principle.

But some of the goals embedded in both marriage neutrality and couples equity almost certainly have convex costs of deviation. Part of the appeal of marriage neutrality is that it removes tax incentives that distort the decision to marry. ${ }^{28}$ Welfare economics demonstrates the costs of such tax-oriented distortions are generally convex. ${ }^{29}$ Similarly, the desire for couples equity derives from a desire for tax equity more generally. Nearly all utility functions that generate tax equity imply that the costs of ever-increasing inequity are convex. For example, diminishing marginal utility is one justification for tax equity and progressive taxation, ${ }^{30}$ and many utility functions with diminishing marginal utility have the degree of diminution of utility decreasing with income, implying convex costs of deviations from equity. ${ }^{31}$

27 It is important to note that the magnitude of violations of principle is easy to measure in this context. The size of a violation of couples equity or marriage neutrality is measured in dollars. When the size of violations of principle is hard to measure, the assumption of convex costs to violations of principle becomes very difficult, if not impossible, to implement.

${ }^{28}$ For a discussion of marriage neutrality, bonuses, and penalties from a marriage incentive perspective, see Zelenak, note 1 , at 30-33.

29 See, e.g., Jonathan Gruber, Public Finance and Public Policy 590-95 (3d ed. 2011).

30 See Louis Kaplow, A Fundamental Objection to Tax Equity Norms: A Call for Utilitarianism, 48 Nat'l Tax J. 497, 497 (1995). For a discussion of the basis for tax equity and a critique of the independent normative function of horizontal equity, see id. at 499-502.

31 See Angus Deaton, Understanding Consumption 2-29 (1992) (demonstrating that constant relative risk aversion (CRRA) utility functions, the workhorse utility functions of economics, exhibit diminishing absolute risk aversion). For an empirical demonstration of CRRA's relevance, see Pierre-André Chiappori \& Monica Paiella, Relative Risk Aversion Is Constant: Evidence from Panel Data, 9 J. Eur. Econ. Ass'n 1021 passim (2011). Even 
Alternatively, choosing to follow either couples equity or marriage neutrality exclusively pushes the costs of coping with the marriage taxation trilemma entirely onto some parties, while leaving other parties unaffected by the trilemma's bite. Behind a Rawlsian veil of ignorance, such a "solution" to the problem of marriage taxation is unappealing. ${ }^{32}$ Rather than coping with the trilemma by disfavoring some taxpayers but not others, taxpayers behind a veil of ignorance should prefer to share the burdens of the trilemma more equally. ${ }^{33}$

In addition, linear costs of deviation that would compel policymakers to adopt one principle in its entirety are generally inapt for the Code, which compromises among a host of competing principles. Indeed, the history of the taxation of marriage demonstrates that neither couples equity nor marriage neutrality is an inviolate principle-our system of taxation, and that of many other countries, has deviated and continues to deviate from both principles. ${ }^{34}$ Muddled compromise is more consistent with convex costs of deviations from multiple principles than other assumptions about the costs of deviations from principles.

For simplicity, I assume that the costs of deviations from couples equity and marriage neutrality are quadratic, a simple convex functional form that is also the form used in ordinary least squares regression and many other contexts. ${ }^{35}$

the administrability argument that underlies couples equity-the fear of income shiftingcontains a convexity. If there is only a small violation of couples equity in the taxation of marriage, then the only income-shifting transactions that occur will have low costs. As the tax rates of individuals within a marriage diverge to a greater degree, the social and economic costs of the income-shifting transactions that follow grow ever larger.

32 See Evan Tsen Lee, On the Received Wisdom in Federal Courts, 147 U. Pa. L. Rev. $1111,1135-36$ (1999), for a concise explanation of the veil of ignorance and maximin decision strategy. When individuals are behind a veil of ignorance with regards to marital status and tax regime, for example, the tax regimes of columns 2 and 3 of Table 1 are unattractive. If a married couple has unequal incomes, then individual filing (the pre-1948 regime) is extremely problematic. $C D$ pays much more than $A B$, in spite of having the same income. If an unmarried couple has unequal income, then the 1948 to 1969 regime (full income-splitting, Table 1 , column $3 a$, tax of $\$ 2000$ on both $A B$ and $C D$ ) is extremely problematic, as the couple pays an extreme singles penalty. If a married couple has equal incomes in the post-1969 regime, then there is a severe marriage penalty. See Table 1, column $3 \mathrm{~b}$. Behind a the veil of ignorance, a marital tax regime with convex costs of violations of principle improves the lot of the most disadvantaged citizen subject to the marital tax system. As a result, the convex cost model is superior from the veil of ignorance perspective. See Lee, supra, at 1136.

33 This assertion could also be proven by assuming that taxpayers are risk-averse and prefer to avoid tax regimes where they bear high taxes in some contexts and low taxes in others. Risk-averse taxpayers prefer taxation of marriage regimes where the "accident" of their marital status and income distribution affects their taxation as little as possible.

34 See McCaffery, note 24 , at $989-91$.

35 The assumption of quadratic deviation costs relative to ideal outcomes, commonly known as loss functions, is common in economics as well as in statistical analysis. See, e.g., Kenneth Rogoff, Optimal Degree of Commitment to an Intermediate Monetary Target, 
My framework allows for different opinions about the relative importance of violations of marriage neutrality and couples equity. A policymaker may prefer to weight one principle more heavily than the other. In addition, the framework disaggregates marriage neutrality into two sub-principles-marriage penalties (such as that encountered by $\mathrm{AB}$ ) and marriage bonuses (such as that encountered by $C D$ ). ${ }^{36}$

A proponent of strict marriage neutrality would not distinguish between marriage penalties and marriage bonuses. Both penalties and bonuses violate marriage neutrality. But it is also possible to feel more strongly about one than the other. If marriage yields positive social externalities, such as better child rearing, then a marriage bonus may be desirable. ${ }^{37}$ My framework also assumes that preferences regarding progressivity are defined by the individual filing schedule. The progressivity of taxes on married couples filing jointly ${ }^{38}$ results from the progressivity of the individual filing schedule and the desire for couples equity and marriage neutrality. ${ }^{39}$

\section{B. The Structure of Marriage Penalties and Bonuses When Both Couples Equity and Marriage Neutrality Can Be Violated}

I now turn to the best structure for taxation of marriage when both couples equity and marriage neutrality become violable principles.

As established above, we cannot achieve couples equity, marriage neutrality, and have a progressive tax system. We can, however, achieve two of the three principles of the trilemma. ${ }^{40}$ But the framework developed in the Appendix and illustrated by Tables 1 through 3 implies that the best tax schedule for married couples satisfies neither couples equity nor marriage neutrality. Why not achieve two of the three principles when it is possible? Because doing so requires an extreme violation of the third, which is socially undesirable. Convex costs of deviations from principle imply that it is better to have small violations of two principles than large violations of one.

100 Q.J. Econ. 1169, 1169-70, 1173-74 (1985) (describing a central banker or social planner wishing to keep both inflation and unemployment at ideal rates and having convex (quadratic) costs of deviation from these partially inconsistent goals).

36 Marriage penalties can also be described as "singles bonuses" and marriage bonuses as "singles penalties."

37 If marriage yields positive externalities, then marriage neutrality should give way to marriage subsidy. In the model, this corresponds to putting more weight on marriage penalties than on marriage bonuses, which would lead to a subsidy. The trilemma remains, though the optimal compromise changes.

38 IRC \& 1(a).

39 This framework could be altered by introducing additional constraints regarding the progressivity of the taxation of married couples filing jointly. For more details, see the Appendix.

40 See notes 4-5 and accompanying text; Table 1, column (4). 
Column (5) from Table 1 provides an example of a marital tax schedule favored by the framework. Income tax for married couples depends upon both joint income and the distribution of the income between the two members of the couple. Under this schedule $A B$ pays $\$ 2500$ in tax and $C D$ pays $\$ 3000$. Neither couples equity nor marriage neutrality is maintained through this tax schedule. $C D$ pays more than $A B$, violating couples equity. $A B$ pays more in tax than under individual filing, while $C D$ pays less in tax than under individual filing, violating marriage neutrality. But the size of the violations of marriage neutrality and couples equity are considerably lower in the column (5) schedule than in the marriage neutrality schedule of column (2) or the couples equity schedule of column (3). Column (2) (marriage neutrality) violates couples equity by $\$ 1500$. Column (3) violates marriage neutrality for $A B$ and $C D$ by a total of $\$ 1500$ : Column (3a) gives a $\$ 1500$ bonus to $C D$, while column (3b) gives a $\$ 1350$ bonus to $C D$ and a $\$ 150$ penalty to $A B$. Column (5), by contrast, violates couples equity by $\$ 500$, violates marriage neutrality by (a penalty of) $\$ 500$ for $A B$ and violates marriage neutrality by (a bonus of) $\$ 500$ for $C D$. The column (5) schedule thus violates couples equity by less than the column (2) individual filing structure and violates marriage neutrality by less than the column (3) joint filing structure. If large violations of either couples equity or marriage neutrality are disproportionately bad relative to small violations of either principle, then the schedule proposed in column (5) is superior to existing treatments of income taxation for married couples. Violating marriage neutrality reduces the size of violations of couples equity, and violating couples equity reduces the size of the violation of marriage neutrality.

\section{Evaluating Policy Under the Framework}

As suggested in the discussion of Table 1, pure individual filing or joint filing schedules for married couples impose the burdens of the trilemma entirely on some taxpayers rather than others. Individual filing maintains marriage neutrality but egregiously violates couples equity. Joint filing has the opposite problem, egregiously violating the principle of marriage neutrality. I now use this framework to evaluate several proposed reforms to these polar solutions to the taxation of marriage.

\section{Optional Individual Filing}

In the late 1990's, the proposed (but unenacted) Marriage Tax Elimination Acts sought to mitigate the marriage penalty by offering married couples the choice between individual filing under $\S 1(\mathrm{c})$ and 
joint filing under $\S 1(\mathrm{a}){ }^{41}$ This proposal had the benefit of simplicity. It called for no new tax brackets or changes in property law. It also would have unambiguously reduced the marriage penalty for couples like AB. Couples would choose individual filing only if it reduced their tax burden.

Column (3) of Table 2 presents a hypothetical tax schedule under optional individual filing for married couples. If $A B$ chooses individual filing and $C D$ chooses joint filing, then neither couples equity nor marriage neutrality is achieved. ( $A B$ would pay less tax than $C D$ in spite of equal combined incomes, and $C D$ would pay less tax than $C$ and $D$ would if they filed individually.) As a result, some argue that optional filing is "strange," "incoherent" and "makes little sense." 42

TABLE 2

Optional Individual fiLING for Married Couples

\begin{tabular}{|c|c|c|c|}
\hline $\begin{array}{l}\text { Taxpayer } \\
\text { (Income) }\end{array}$ & $\begin{array}{c}\text { Tax if Single } \\
\text { (1) }\end{array}$ & $\begin{array}{l}\text { Married Individual Filing } \\
\text { (Marriage Neutrality) } \\
\text { (2) }\end{array}$ & $\begin{array}{l}\text { Choice of Individual Filing } \\
\text { or Joint Filing } \\
\text { (3) }\end{array}$ \\
\hline $\begin{array}{c}\mathrm{A} \\
(\$ 10,000)\end{array}$ & $\$ 1000$ & \multirow[t]{2}{*}{$\begin{array}{l}\$ 2000 \\
\text { (No change in tax on } \\
\text { marriage) }\end{array}$} & \multirow[t]{2}{*}{$\begin{array}{l}\$ 2000 \\
\text { Choose Individual Filing, } \\
\text { col. (2) }\end{array}$} \\
\hline $\begin{array}{c}\text { B } \\
(\$ 10,000)\end{array}$ & $\$ 1000$ & & \\
\hline$\underset{(\$ 0)}{C}$ & $\$ 0$ & \multirow[t]{2}{*}{$\begin{array}{l}\$ 3500 \\
\text { (No change in tax on } \\
\text { marriage) }\end{array}$} & \multirow[t]{2}{*}{$\begin{array}{l}\$ 2150 \\
\text { Choose Joint Filing, Table } \\
1, \text { col. (3b) }\end{array}$} \\
\hline $\begin{array}{c}\mathrm{D} \\
(\$ 20,000)\end{array}$ & $\begin{array}{l}\$ 3500= \\
\$ 1000+ \\
\$ 2500\end{array}$ & & \\
\hline
\end{tabular}

Table Description: For individual filing, columns (1) and (2), akin to $\S 1$ (c) filing, reflect a $10 \%$ marginal rate on the first $\$ 10,000$ of income and a $25 \%$ marginal rate on income in excess of $\$ 10,000$. Column (2) presents total taxes paid by each couple. Column (3) shows the choice each couple would make between married individual filing (Table 2, column (2)) and married joint filing (Table 1, column (3b)).

The framework developed here provides some theoretical coherence to optional individual filing. Optional individual filing creates the possibility of couples inequity but limits the size of marriage neutrality violations with respect to marriage penalties. If a couple pays too much of a marriage penalty, then they will choose individual filing. The end result, with some violation of marriage neutrality and couples

41 See Marriage Tax Elimination Act, H.R. 2456, 105th Cong. $§ 2$ (1997); Marriage Tax Elimination Act, S. 1314, 105th Cong. \$ 2 (1997).

42 See, e.g., Zelenak, note 1 , at 17-18. 
equity but fewer egregious violations of either, may be more desirable than the status quo.

Optional $\S 1$ (c) filing is no panacea, however. It ensures that married couples either benefit from joint filing or are unaffected by marriage. Unmarried couples by contrast, enjoy no such option and therefore are systematically disfavored. The availability of $\S 1$ (c) filing to married couples and the desire for couples equity also constrains the $\S 1$ (a) joint filing obligation from being increased substantially-to do so would create substantial couples inequity for couples who do not opt in-thereby ensuring the continuation of large marriage bonuses for couples with unequal income. In total, optional $\S 1$ (c) filing therefore "compromises" between marriage neutrality and couples equity in an arbitrary fashion.

\section{Child Care Tax Benefits and Couples Equity}

Although the joint filing schedule of $\S 1$ (a) provides for couples equity, other provisions of the Code undermine the marital tax schedule's fidelity to couples equity. Suppose that $A B$ and $C D$ both have one dependent child. Both $A B$ and $C D$ pay for child care. The terms of the child care tax credit and dependent care flexible spending accounts provide that $A B$ can obtain preferential tax treatment for up to $\$ 5000$ in child care expenses. ${ }^{43} C D$, by contrast, is not eligible for the tax preferences because the preferences cannot be greater than the income of either member of the couple, and $C$ has no income. ${ }^{44}$

Because $A B$ can receive tax preferences that $C D$ cannot because of $C$ 's lack of income, the child care tax expenditures violate couples equity. Suppose married couples $A B$ and $C D$ with $\$ 20,000$ in income each owe $\$ 3000$ in taxes. The child care tax expenditures reduce the $\$ 3000$ obligation for $A B$ to $\$ 2500$. This violation of couples equity is a desirable one in my framework. A small degree of couples inequity is introduced, but the large marriage bonus for $C D$ is reduced, a worthwhile trade-off if large deviations from principles are more costly than small ones.

Many European countries apply a similar "compromise" position to the taxation of marriage broadly. Tax is determined individually, but some forms of income for one spouse can benefit from splitting with the other spouse and benefits are determined based on combined income. The combined tax-and-transfer system of these countries therefore exhibits a hybrid of marriage neutrality and couples equity,

\footnotetext{
43 IRC $\S \S 21(\mathrm{c}), 129(\mathrm{a})(2)(\mathrm{A})$.

44 IRC $\$ \S 21(\mathrm{c}), 129(\mathrm{~b})(1)$. Note that, under some circumstances (for example, $C$ is a full-time student), $C$ will be imputed income, and $C D$ will receive a deduction. IRC $\S \S 21(d)(2), 129(b)(2)$.
} 
adhering to neither but avoiding large deviations from either principle. ${ }^{45}$

\section{Implementing the Ideal Policy: Reforming Married Filing Separately}

While optional individual filing and tax expenditures for child care expenses both create couples inequity and reduce marriage non-neutrality, neither provides a comprehensive solution to the taxation of marriage. Tax expenditures for child care reduce non-neutralities only for those with children and are subject to many restrictions. Optional individual filing reduces marriage penalties by introducing the possibility of couples inequity but fails to address egregious violations of marriage neutrality in the form of marriage bonuses or singles penalties.

Taxation of marriage can achieve partial adherence to the principles of couples equity and marriage neutrality through reform of the married filing separately schedule of $\S 1$ (d) and a simultaneous change in the brackets of $\S 1$ (a) (married filing jointly). ${ }^{46}$ Currently, married couples choose between the married filing jointly schedule of $\S 1$ (a) and the married filing separately schedule of $\S 1(\mathrm{~d})$. Section 1(d)'s bracket and rate structure, however, make it an unattractive schedule for nearly all married couples. ${ }^{47}$ Few couples choose to file separately. ${ }^{48}$ But $\S 1$ (d)'s schedule could be reformed to reduce the marriage penalty for couples with equal incomes (such as $A B$ ), while leaving couples with unequal incomes unaffected. A reformed $\S 1(\mathrm{~d})$ would mitigate violations of marriage neutrality, allowing a reformed $\S 1$ (a) joint filing schedule to offer less of a bonus to couples with unequal incomes. Section 1(d) would act as a relief valve, preventing a less favorable $\$ 1(a)$ schedule from imposing an egregious marriage penalty on couples with equal income.

Reforming $\S 1(\mathrm{~d})$ separate filing is distinct from granting couples the option to file individually under $\S 1(\mathrm{c})$. As discussed above, optional $\S 1(c)$ filing was too favorable towards marriage. Reformed

45 See Jonathan R. Kesselman, Income Splitting and Joint Taxation of Couples: What's Fair?, 14 IRPP Choices 1, 14-17 (2008), http://archive.irpp.org/choices/archive/ vol14no1.pdf.

46 Other reforms, such as earnings credits for second earners, could achieve the same thing. See McCaffery, note 24, at 1001.

47 Cases in which married couples may choose to file separately include estrangement, fear of liability associated with filing a joint return, and the ability to take advantage of a deduction for unreimbursed medical expenses that must exceed $10 \%$ of adjusted gross income. See IRC $\S 213$. In Table 3 I assume that none of these considerations apply to $A B$ or $C D$.

48 See IRS, Statistics of Income 2011: Individual Income Tax Returns 82 tbl.1.6 (2013). 
$\S 1$ (d) filing, by contrast, would retain a (reduced) marriage penalty for couples with equal incomes. As a result, income tax obligations under $\S 1$ (a) could be increased without creating dramatic couples inequities, thereby mitigating the marriage bonus or singles penalty of the taxation of marriage to a greater degree than optional $\S 1$ (c) filing.

Table 3 illustrates the flaws of the current $\S 1(d)$ in column (4) and the merits of a reformed $\S 1(d)$ and reformed $\S 1(a)$ in columns (5) and $(3 b)$.

TABLE 3

Reform Proposal for Married Filing Separately

\begin{tabular}{|c|c|c|c|c|c|c|}
\hline $\begin{array}{l}\text { Taxpayer } \\
\text { (Income) }\end{array}$ & $\begin{array}{l}\text { Tax if } \\
\text { Single }\end{array}$ & $\begin{array}{l}\text { Married } \\
\text { Individual Filing } \\
\text { Marriage } \\
\text { Neutrality) } \\
\\
\\
\text { (2) }\end{array}$ & 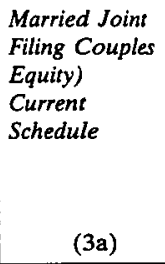 & $\begin{array}{l}\text { Married Joint } \\
\text { Filing Couples } \\
\text { Equity) } \\
\text { Reform } \\
\text { Proposal in } \\
\text { Conjunction } \\
\text { with Reform to } \\
\text { \$1(d) (3b) }\end{array}$ & $\begin{array}{c}\text { Current } \$ 1(d) \\
\text { Schedule } 10 \% \\
\text { Marginal Rate } \\
\text { on First } \$ 5000 \text {, } \\
25 \% \text { on Excess } \\
\text { (4) }\end{array}$ & \begin{tabular}{l} 
Reformed \\
$\$ 1(d)$ Schedule \\
$10 \%$ Marginal \\
Rate on First \\
$\$ 8000,25 \%$ \\
on Excess \\
\\
\multicolumn{1}{c}{$(5)$}
\end{tabular} \\
\hline $\begin{array}{c}A \\
(\$ 10,000)\end{array}$ & $\$ 1000$ & \multirow[t]{2}{*}{$\begin{array}{l}\$ 2000 \\
\text { (No change in } \\
\text { tax on } \\
\text { marriage) }\end{array}$} & \multirow[t]{2}{*}{$\begin{array}{l}\$ 2150 \\
\text { (Same as CD) }\end{array}$} & \multirow[t]{2}{*}{$\begin{array}{l}\$ 3050 \\
\text { (Same as } \mathrm{CD} \text { ) }\end{array}$} & $\$ 1750$ & $\$ 1300$ \\
\hline $\begin{array}{c}\text { B } \\
(\$ 10,000)\end{array}$ & $\$ 1000$ & & & & $\begin{array}{l}\$ 1750 \\
\text { Combined } \\
\text { Tax }=\$ 3500 \\
\text { (AB chooses } \\
\text { 1(a) filing from } \\
\text { col. (3a)) }\end{array}$ & $\begin{array}{l}\$ 1300 \\
\text { Combined } \\
\text { Tax }=\$ 2600 \\
\text { (Lower than col. } \\
(3 \mathrm{~b}) \text { tax of } \\
\$ 3050)\end{array}$ \\
\hline$\underset{(\$ 0)}{C}$ & $\$ 0$ & \multirow[t]{2}{*}{$\begin{array}{l}\$ 3500 \\
\text { (No change in } \\
\text { tax on } \\
\text { marriage) }\end{array}$} & \multirow[t]{2}{*}{$\begin{array}{l}\$ 2150 \\
\text { Same as } \mathrm{AB} \text { ) }\end{array}$} & $\begin{array}{l}\$ 3050 \\
\text { (Same as AB) }\end{array}$ & $\$ 0$ & $\$ 0$ \\
\hline$\underset{(\$ 20,000)}{\text { D }}$ & $\begin{array}{l}\$ 3500 \\
= \\
\$ 1000 \\
+ \\
\$ 2500\end{array}$ & & & & $\begin{array}{l}\$ 4250 \\
(\mathrm{CD} \text { chooses } \\
\$ 1(\mathrm{a}) \text { filing } \\
\text { from col. (3a)) }\end{array}$ & $\begin{array}{l}\$ 3800 \\
\text { (CD chooses } \\
\$ 1(a) \text { filing } \\
\text { from col. }(3 b))\end{array}$ \\
\hline
\end{tabular}

Table Description: For individual filing, columns 3(b) and (2), akin to $\S 1$ (c) filing, apply a $10 \%$ marginal rate on the first $\$ 10,000$ of income and a $25 \%$ marginal rate on income in excess of $\$ 10,000$. For married joint filing, akin to $\S 1$ (a) from 1969 to the present, column (3a) applies a $10 \%$ marginal rate on the first $\$ 19,000$ of income and a $25 \%$ marginal rate on income in excess of $\$ 19,000$. For reformed joint filing under $\S 1(\mathrm{a})$, column $(3 \mathrm{~b})$ reflects a $10 \%$ marginal rate on the first $\$ 13,000$ of income and a $25 \%$ marginal rate on income in excess of $\$ 13,000$. For married filing separately $(\$ 1(d))$ under the current regime, column (4), there is a $10 \%$ marginal rate on the first $\$ 5000$ of income and a $25 \%$ marginal rate on income in excess of $\$ 5000$. For 
married filing separately ( $\$ 1(\mathrm{~d})$ ) under this Article's reform proposal (column (5)), there is a $10 \%$ marginal rate on the first $\$ 8000$ of income and a $25 \%$ marginal rate on income in excess of $\$ 8000$.

Column 4 depicts the current married filing separately schedule. Note that under that schedule, both $A B$ and $C D$ pay more than they would by filing jointly as in column (3a). Thus, no one chooses to file under this schedule. The reformed $\S 1$ (d) schedule of column (5) $(10 \%$ tax rate on the first $\$ 8000$ of income, with a $25 \%$ rate thereafter), becomes attractive for $\mathrm{AB}$, as the combined $\$ 2600$ in tax they owe filing under $\S 1$ (d) is less than the $\$ 3050$ they owe under the reformed $\S 1$ (a) joint filing schedule illustrated in column (3b). $C D$, however, chooses to pay $\$ 3050$ under the reformed $\$ 1$ (a) of column (3b) rather than the amount owed under $\S 1$ (d) of $\$ 3800$. A reformed $\S 1$ (d) and $\S 1(\mathrm{a})$ therefore mitigate violations of both marriage neutrality and couples equity. (Note that the numbers could be changed as needed.) $A B$ pays a marriage penalty of $\$ 600$. $C D$ enjoys a marriage bonus of $\$ 450$. $A B$ pays $\$ 450$ less in taxes than $C D$. There are thus violations of couples equity, marriage bonuses, and marriage penalties, but the size of all of these violations is smaller than the worst violations under any of the other reform proposals. ${ }^{49}$ With couples equity and progressivity, by contrast, $C D$ enjoys a marriage bonus of $\$ 1500$.

By doing nothing more radical than adjusting the brackets of the two already-existing filing options for married couples, reforming $\S 1$ (d) and $\S 1(\mathrm{a})$ 's schedules achieves a sensible compromise between marriage neutrality and couples equity. ${ }^{50}$ Compromise in the taxation of marriage of the sort advocated here is therefore comparatively simple to achieve.

\section{Secondary Earner Incentives}

One problem with violations of marriage neutrality that has received little attention in this article is the impact of joint filing on second earners' incentives to work. Joint filing implies that the marginal tax rate is the same for both spouses in a married couple. Effectively, the primary earner's marginal rate goes down while the secondary

49 If $A B$ were given the option of filing under $\S 1(\mathrm{~b})$, then $A B$ would pay $\$ 2000$. If nothing else were changed in Table 3 , then there would be a marriage bonus of $\$ 450$ for $C D$ and a $\$ 1050$ violation of couples equity between $A B$ and $C D$.

50 When married couples file separately in community property states, they obtain the opportunity to split income under Poe v. Seaborn, 282 U.S. 101 (1930). Because the married filing separately rate is generally less advantageous to the lower-earning spouse than the individual filing rate, such income-splitting opportunities loom smaller with married filing separately than they do under individual filing, though income splitting remains an issue. See McCaffery, note 24, at 989 n.17. 
earner's marginal rate rises. Many commentators have argued that this is inefficient - the labor supply of secondary earners is highly elastic. $^{51}$ It also reinforces stereotypical gender roles. Secondary earners are disproportionately women and reducing their incentive to work encourages them to stay at home. 52

Not surprisingly, the policy proposals examined here ameliorate but do not eliminate this negative side effect of joint filing. They ameliorate the secondary earner incentive effect because they move marital taxation closer to marriage neutrality than traditional joint taxation. They do not eliminate the secondary earner bias because they fail to achieve perfect marriage neutrality.

Consider the reformed $\S 1$ (a) and $\S 1$ (d) proposal put forth in the previous Subsection. This proposal either would eliminate the secondary earner problem entirely or would not affect it at all. $C D$ would be unlikely to file under $\S 1$ (d) because the splitting benefit of joint filing would be so large. As a result, $C$ 's marginal tax rate for the first hour of work would be $25 \%$, the highest marginal rate. But other secondary earners might benefit. Consider a couple $E F$ where $E$ makes $\$ 13,000$ and $F$ makes $\$ 7000$. EF save money by choosing reformed $\S 1(\mathrm{~d})$ separate filing, which would impose income taxes of $\$ 2050$ on $E$ and $\$ 700$ on $F$ for a total of $\$ 2750$, over reformed $\S 1$ (a), which would impose a tax of $\$ 3050$ (column 3b). With the reform to $\S 1($ a) and $\S 1$ (d) proposed above, $F$ s marginal rate would become $10 \%$, meaning that $\mathrm{F}$ is taxed at the lowest marginal rate.

A similar story can be told for many of the other reform initiatives presented here, including the ones original to this Article. They generally improve but do not eliminate the increase in marginal rates of secondary earners generated by marriage.

\section{Progressive Marginal Rates and the Taxation of Marriage}

Previous discussions of the taxation of marriage avoid consideration of progressive income tax rates. Although progressivity is required to create the battle of the neutralities, progressivity is assumed to be a separate principle, derived from priorities unlike the foundations of marriage neutrality or couples equity. ${ }^{53}$ My framework does not delve into the foundations of progressivity. Nevertheless, progressivity is in-

51 See, e.g., Gruber \& Saez, note 12, at 4; Chris William Sanchirico, Progressivity and Potential Income: Measuring the Effect of Changing Work Patterns on Income Tax Progressivity, 108 Colum. L. Rev. 1551, 1582 (2008).

52 See McCaffery, note 1 , at 120-26.

53 E.g. Smith, note 4, at $152 \mathrm{n} .15$ (assuming progressive rates and arguing that "the real challenge of the trilemma is to accommodate this basic assumption of progressive rates with the least objectionable of the remaining alternatives"). 
cluded as a choice variable in the model. Unless the current degree of progressivity is a sacred principle that cannot be compromised, we may want to sacrifice some degree of progressivity in order to reduce the size of violations to the principles of marriage neutrality and couples equity.

The argument is by now a familiar one. Suppose that the progressivity of individual tax schedules is sacrosanct. This creates considerable pressure on marriage neutrality and couples equity. Indeed, the focus of this Article to this point has been how to best handle this tension. But imagine a small movement towards a more linear tax system. That is, a rate schedule that is progressive but slightly less than currently so. This should not "cost" too much in terms of progressivity. The revised degree of progressivity is only slightly less progressive than the ideal schedule. This small change, however, reduces relatively large deviations from the principles of marriage neutrality and couples equity. If large deviations from principle are disproportionately more problematic than small deviations, then the degree of progressivity should be reduced to reduce the tension between marriage neutrality and couples equity. The degree to which progressivity should be sacrificed depends upon the relative weight assigned to violations of progressivity versus violations of marriage neutrality and couples equity. But even if violations of progressivity are considered much more important than violations of the other two principles, the framework developed here still calls for some reduction in progressivity relative to the ideal amount. Table 4 illustrates this policy prescription.

TABLE 4

Reform Proposal with Adjusted Progressivity

\begin{tabular}{|c|c|c|c|c|c|}
\hline $\begin{array}{l}\text { Taxpayer } \\
\text { (Income) }\end{array}$ & $\begin{array}{l}\text { Tax if } \\
\text { Single }\end{array}$ & $\begin{array}{l}\text { Married } \\
\text { Individual Filing } \\
\text { (Marriage Neutrality) } \\
\text { (2) }\end{array}$ & $\begin{array}{l}\text { Married Joint Filing } \\
\text { (Couples Equity) } \\
\text { Current Schedule, } \\
\text { Less Progressivity } \\
\text { (3a) }\end{array}$ & $\begin{array}{c}\text { Married Joint Filing } \\
\text { (Couples Equity) } \\
\text { Reform Proposal } \\
\text { (3b) }\end{array}$ & \begin{tabular}{l} 
Reformed \$ I (d) \\
Schedule of $12 \%$ \\
Marginal Rate on \\
First $\$ 8000,23 \%$ \\
on Excess \\
\multicolumn{1}{c}{ (4) }
\end{tabular} \\
\hline$\underset{(\$ 10,000)}{A}$ & $\$ 1200$ & \multirow[t]{2}{*}{$\begin{array}{l}\$ 2400 \\
\text { (No change in tax on } \\
\text { marriage) }\end{array}$} & \multirow[t]{2}{*}{$\begin{array}{l}\$ 2510 \\
\text { (Same as CD) }\end{array}$} & \multirow[t]{2}{*}{$\begin{array}{l}\$ 3170 \\
\text { (Same as CD) }\end{array}$} & $\$ 1420$ \\
\hline $\begin{array}{c}\text { B } \\
(\$ 10,000)\end{array}$ & $\$ 1200$ & & & & $\begin{array}{l}\$ 1420 \\
\text { Combined Tax }= \\
\$ 2840 \\
\text { (Lower than col. (3b) } \\
\text { tax of } \$ 3170)\end{array}$ \\
\hline $\begin{array}{c}\mathrm{C} \\
(\$ 0)\end{array}$ & $\$ 0$ & \multirow[t]{2}{*}{$\begin{array}{l}\$ 3500 \\
\text { (No change in tax on } \\
\text { marriage) }\end{array}$} & \multirow[t]{2}{*}{$\begin{array}{l}\$ 2510 \\
\text { (Same as AB) }\end{array}$} & \multirow[t]{2}{*}{$\begin{array}{l}\$ 3170 \\
\text { (Same as } \mathrm{AB} \text { ) }\end{array}$} & $\$ 0$ \\
\hline$\underset{(\$ 20,000)}{\text { D }}$ & $\begin{array}{l}\$ 3500= \\
\$ 1200+ \\
\$ 2300\end{array}$ & & & & $\begin{array}{l}\$ 3720 \\
(C D \text { chooses } \& 1(a) \\
\text { filing from col. (3b)) }\end{array}$ \\
\hline
\end{tabular}


Table Description: For individual filing, columns (1) and (2) apply a $12 \%$ marginal rate on the first $\$ 10,000$ of income and a $23 \%$ marginal rate on income in excess of $\$ 10,000$. For married joint filing, akin to a less progressive $\S 1$ (a) from 1969 to the present, column (3a) applies a $12 \%$ marginal rate on the first $\$ 19,000$ of income and a $23 \%$ marginal rate on income in excess of $\$ 19,000$. For married joint filing, column (3b) applies this Article's reformed $\$ 1$ (a) of a $12 \%$ marginal rate on the first $\$ 13,000$ of income and a $23 \%$ marginal rate on income in excess of $\$ 13,000$. For married filing separately ( $\$ 1(d)$ ) under this Article's reform proposal (column (4)), there would be a $12 \%$ marginal rate on the first $\$ 8000$ of income, and a $23 \%$ marginal rate on income in excess of $\$ 8000$.

Table 4 modifies the individual marginal rate structure applied in Tables 1 through 3 . In Table 4 , the first bracket is taxed at a $12 \%$ rate rather than the $10 \%$ of Tables 1 through 3 . The marginal rate on income in the second bracket is $23 \%$ in Table 4 , rather than $25 \%$ as in Tables 1 through 3 . These modifications make Table 4's rate structure less progressive than the previous structure. But only slightly. No one's taxes change dramatically. The poor pay a bit more, the rich slightly less.

The less progressive rate structure of all columns in Table 4 reduces the scope of the couples equity or marriage neutrality trade-off emphasized in the previous Parts. If marriage neutrality was maintained, as in Table 4 (columns (1) and (2)), couples equity would be violated by $\$ 1100$, rather than the $\$ 1500$ violation that characterized individual filing in Tables 1 through 3 . If couples equity was maintained, as in Table 4, column (3a), the size of marriage bonuses and penalties would be reduced. Whatever tax obligation is chosen for joint filers with incomes of $\$ 20,000$ (in column (3a) the obligation is $\$ 2510$ ), the total value of marriage penalties and bonuses would be $\$ 1100$, rather than $\$ 1500$ as in previous tables. Finally, if neither marriage neutrality nor couples equity was maintained (column (4)), as in the reform of the $\S 1$ (a) (column (3b)) and $\S 1$ (d) (column (4)) married filing separately schedules, then marriage taxation would be characterized by relatively small violations of the principles of progressivity, marriage neutrality $(A B$ would pay a marriage penalty of $\$ 440, C D$ would receive a marriage bonus of $\$ 330$ ), and couples equity ( $C D$ would pay $\$ 330$ more in taxes than $A B$ ).

The problems of marriage taxation do not imply that progressivity should be disregarded. But progressivity is not a Boolean variable. Tax rates can be more or less progressive. Society may wish to reduce the degree of progressivity to reduce violations of couples equity and/ or marriage neutrality. The weight given to violations of ideal 
progressivity relative to couples equity or marriage neutrality determines the size of the change to the progressive rate structure. Higher weights on progressivity imply smaller changes to the progressive rate structure

\section{Conclusion}

I began with the trilemma of marriage taxation. Marriage taxation can comply with only two principles from among the three-progressivity, marriage neutrality, and couples equity. But the framework developed here reframes the question. Just as drawing a line of "best fit" to a plot of data is not an insoluble problem simply because all the data points do not align, so too marriage taxation is not an insoluble problem to be left to debaters arguing the merits of which of the three principles to discard. In drawing a best fit line, the goal is to minimize deviations between the line and given points, with disproportionately greater weight given to large deviations, which render the line much less valuable as a predictive tool. Similarly, the marriage taxation trilemma should be solved by achieving a tax schedule of "best fit" between the principles of progressivity, marriage neutrality, and couples equity. Large deviations from any of these three principles should be avoided, as a large deviation from a valuable principle is disproportionately more offensive than a smaller deviation. As a result, none of the principles receives absolute fealty, just as no point in a plot of data is guaranteed to be on the "best fit" line.

The arguments about the relative merits of progressivity, couples equity, and marriage neutrality remain. But they are arguments of degree-how much weight should one principle receive relative to the other-rather than of kind.

The framework developed here may have broader application in tax scholarship. International tax scholars debate the merits of capital import neutrality versus capital export neutrality. ${ }^{54}$ Both "neutralities" have their advocates, but an international tax system cannot achieve both. ${ }^{55}$ The framework developed here suggests that perhaps the tax system should not try. If both "neutralities" are desirable, then a system that achieves partial but imperfect fealty to both is probably better than a system that achieves one or the other absolutely.

\footnotetext{
54 For a discussion, see Charles E. McLure, Jr., Must Corporate Income Be Taxed Twice? 204-16 (1979).

55 See Daniel N. Shaviro, Fixing U.S. International Taxation 121-41 (2014).
} 


\section{Appendix}

Assume that there are four taxpayers, $A, B, C$, and $D . A B$ is one couple and $C D$ is another couple. Assume that $A B$ 's income equals $C D$ 's income and that $C D$ 's income is more unequal than $A B$ 's income. Let $T(A), T(B), T(C)$, and $T(D)$ be the income tax owed by each individual under $\S 1$ (c). This framework can be generalized with little additional insight but considerable additional notation as explained below. Let $T(A B)$ and $T(C D)$ be the tax each couple owes if they are married. Assume the following social welfare (or loss) function for taxation of marital incomes:

$\left.\left.\alpha[T(A B)-(T(A)+T(B))]^{2}+\beta\right] T(C D)-(T(C)+T(D))\right]^{2}=\gamma[T(A B)-$ $T(C D)]^{2}$

Where $\alpha$ is the relative social importance placed on marriage penalties, $\beta$ is the relative social importance placed on marriage bonuses/ singles penalties, and $\gamma$ is the relative social importance placed on violations of couples equity. The loss function is quadratic. Social welfare goes down with the square of the deviation from marriage neutrality (bonus/penalty) and couples equity. The quadratic loss function implies that large violations of marriage neutrality, couples equity, or both are considerably worse than smaller violations.

A social planner seeks a marital taxation regime that maximizes social welfare given relevant constraints. Suppose that the social planner's commitment to progressivity exogenously dictates the value of $T(A), T(B), T(C)$, and $T(D)$, with $T(C)+T(D)>T(A)+T(B)$, [Assumption $\mathrm{P}]$.

\section{Solution for Section III.C}

Assume that the individual progressive rate structure is inviolable, such that $T(A), T(B), T(C)$, and $T(D)$ are fixed exogenously. For simplicity, assume that $T(C)$ equals zero. Adherence to couples equity and marriage neutrality is desirable. The social planner's problem given the loss function of Equation (1) now becomes:

$\max _{T(A B), T(C D)} \alpha[T(A B)-(T(A)+T(B))]^{2}+\beta[T(C D)-(T(C)+T(D))]^{2}$ $+\gamma[T(A B)-T(C D)]^{2}$,

yielding the following first order conditions:

$$
\begin{aligned}
& \frac{\partial U}{\partial T(A B)}=2 \alpha[T(A B)-(T(A)+T(B))]+2 \gamma[T(A B)-T(C D)]=0 \\
& \frac{\partial U}{\partial T(C D)}=2 \beta[T(C D)-(T(C)+T(D))]-2 \gamma[T(A B)-T(C D)]=0
\end{aligned}
$$

These first order conditions imply the following proposition:

Proposition 1: If the social welfare function values avoiding marriage penalties, marriage bonuses, and couples inequity $(\alpha>0, \beta>0, \gamma$ 
$>0$ ), then optimal taxation of marriage achieves neither marriage neutrality nor couples equity.

Proof:

$$
T(C)=0
$$

Solving for $T(A B)$ and $T(C D)$ in Equations (2) and (3) yields

$$
\begin{aligned}
& T(A B)=\frac{\beta \gamma T(D)+(\alpha \gamma+\alpha \beta) T(A)+(\alpha \gamma+\alpha \beta) T(B)}{(\beta+\alpha) \gamma+\alpha \beta} \\
& T(C D)=\frac{(\beta \gamma+\alpha \beta) T(D)+\alpha \gamma T(A)+\alpha \gamma T(B)}{(\beta+\alpha) \gamma+\alpha \beta}
\end{aligned}
$$

From Assumption $\mathrm{P}, T(D)=T(A)+T(B)+\varepsilon$, epsilon is positive so

$T(A B)=\frac{\beta \gamma \epsilon+(\alpha \gamma+\alpha \beta+\beta \gamma) T(A)+(\alpha \gamma+\alpha \beta+\beta \gamma) T(B)}{(\beta+\alpha) \gamma+\alpha \beta}$

$T(C D)=\frac{(\beta \gamma+\alpha \beta) \epsilon+(\alpha \gamma+\alpha \beta+\beta \gamma) T(A)+(\alpha \gamma+\alpha \beta+\beta \gamma) T(B)}{(\beta+\alpha) \gamma+\alpha \beta}$

Since $(\beta \gamma+\alpha \beta)>\beta \gamma$ and the rest of the numerator and denominator of Equations (4) and (5) are identical, $T(C D)>T(A B)$, which violates couples equity.

For violation of marriage neutrality, Equation 4 simplifies to

$$
T(A B)=\frac{\beta \gamma \epsilon}{(\beta+\alpha) \gamma+\alpha \beta}+T(A)+T(B), \text { so }
$$

$T(A B) \neq T(A)+T(B)$. Plugging in $T(D)-\varepsilon=T(A)+T(B)$ into the solution for $T(C D)$ yields

$T(C D)=\frac{(\beta \gamma+\alpha \beta) T(D)+\alpha \gamma(T(D)-\epsilon)}{(\beta+\alpha) \gamma+\alpha \beta}=T(D)-\frac{\alpha \gamma \epsilon}{\beta \gamma+\alpha \gamma+\alpha \beta}$,

so $T(C D) \neq T(D)$, violating marriage neutrality.

The proof also demonstrates that $T(A B)>T(A)+T(B)$ and $T(C D)$ $<T(D)$-couples equity-is achieved only if $\alpha=0$, which is ruled out by assumption, or if $T(A B)=T(A)+T(B)$. Equation (3) implies that $T(A B)=T(C D)$-couples equity-is achieved only if $\beta=0$, which is ruled out by assumption, or if $T(C D)=T(C D)+T(D)$. Thus couples equity can be achieved only if $T(A)+T(B)=T(C D)+T(D)$. But this cannot be true because of Assumption $P$ above. So couples equity cannot be achieved in this maximization context. If couples equity is not possible, $T(A B) \neq T(C D)$, then Equation (2) and $\alpha>0, \gamma>0$ imply that $T(A B) \neq T(A)+T(B)$, and Equation (3) and $\beta>0, \gamma>0$ imply 
that $T(C D) \neq T(C)+T(D)$. Marriage neutrality is thus violated. There are both marriage penalties and marriage bonuses. ${ }^{56}$

Solution for Section IV

Relax Assumption $\mathrm{P}$ that the $\S 1$ (c) progressive individual filing tax schedule is not subject to change. Instead, assume that there is a socially desired degree of progressivity. For simplicity, assume that ideal progressivity is given by where $K>1$. Now the social welfare function of Equation (1) is modified as follows:

$\alpha[T(A B)-(T(A)+T(B))]^{2}+\beta[T(C D)-(T(C)+T(D))]^{2}+\gamma[T(A B)-$ $\left.T(C D)]^{2}+\delta[T(D)-\kappa(T(A))+T(B))\right]^{2}$

Equation (6) simplifies to Equation (1) if $\delta$, the social weight placed on violations of the desired progressive individual tax schedule, approaches infinity, meaning that society is not willing to compromise on its desired progressive tax schedule. With Equation (6), the social planner's problem becomes

$$
\begin{aligned}
\max _{T(A B), T(C D), T(A), T(B), T(D)} \alpha[T(A B)-(T(A)+T(B))]^{2} \\
+\beta[T(C D)-(T(C)+T(D))]^{2}+\gamma[T(A B)-T(C D)]^{2} \\
+\delta[T(D)-\kappa(T(A)+T(B))]^{2}
\end{aligned}
$$

Yielding first order conditions with respect to $T(A B)$ and $T(C D)$ that are the same as Equations (2) and (3), as well as

$$
\begin{gathered}
\frac{\partial U}{\partial T(A)}=-2 \alpha[T(A B)-(T(A)+T(B))]-2 \delta \kappa[T(D)-\kappa(T(A)+T(B))]=0 \\
\frac{\partial U}{\partial T(B)}=-2 \alpha[T(A B)-(T(A)+T(B))]-2 \delta \kappa[T(D)-\kappa(T(A)+T(B))]=0 \\
\frac{\partial U}{\partial T(D)}=-2 \beta[T(C D)-(T(C)+T(D))]-2 \delta \kappa[T(D)-\kappa(T(A)+T(B))]=0 \\
\frac{\partial U}{\partial T(A B)}=2 \beta[T(A B)-(T(A)+T(B))]-2 \gamma[T(A B)-T(C D)]=0 \\
\frac{\partial U}{\partial T(C D)}=2 \beta[T(C D)-(T(C)+T(D))]-2 \gamma[T(A B)-T(C D)]=0
\end{gathered}
$$

Proposition 2: If the social welfare function values progressivity, marriage neutrality (with respect to both penalties and bonuses), and couples inequity $(\alpha>0, \beta 0, \gamma>0, \delta>0)$, then the optimal taxation of marriage does not maintain the ideal degree of progressivity, fails marriage neutrality, and fails couples equity.

56 Solving the first order conditions for $T(A B)$ and $T(C D)$ produces little of note. Higher social weights placed on marriage penalties, bonuses, and couples equity produce smaller marriage penalties, bonuses, and couples inequity, respectively. 


\section{Proof:}

Rather than solving this involved system of equations, I note that each equation consists of two principles. The first and second equations involve marriage neutrality for $\mathrm{AB}$ and ideal progressivity. The third equation involves marriage neutrality for $C D$ and ideal progressivity. The fourth equation involves marriage neutrality for $A B$ and couples equity, and the fifth equation involves marriage neutrality for $\mathrm{CD}$ and couples equity. Thus, if one of the principles is violated, then all the principles must be violated. If one of the principles is violated, then a part of one of the equations is nonzero. To make the first order condition true, the other part of the equation must be violated, meaning that another of the principles must be violated. By the same argument, the violation of a second principle implies the violation of a third principle and the fourth. So if any one principle is violated, then they are all violated. We know from the "trilemma" that all of the principles cannot be maintained. So at least one principle must be violated, meaning that they are all violated.

\section{Generalizing the Proofs}

For simplicity, the proofs involved a four-person, two-couple economy. But the proofs can be generalized as follows. Assume that there are $N$ couples and $2 N$ people. The jth couple has income of $I_{j}=\mathrm{I}_{j}^{1}+{ }_{j}^{2}$, where $I_{j}^{1}$ denotes the income of the first member of the couple. Taxes for the $j$ th couple are given by $T(j)$ and the taxes of the first member of the couple if filing individually are $T\left(I_{j}^{1}\right.$ and given exogenously by the desire for progressivity. A generalized social loss function with respect to the taxation of marriage would be

$$
\sum_{j=1}^{N}\left\{\alpha\left[T\left(I_{j}\right)-T\left(I_{j}^{1}\right)-T\left(I_{j}^{2}\right)\right]^{2}+\gamma \sum_{j=1}^{N} W E I G H T\left(I_{j^{\prime}} \sim I_{j}\right)\left[T\left(I_{j}\right)-T\left(I_{j^{\prime}}\right)\right]^{2}\right\},
$$

where $\left(I_{j} \sim I_{j}\right.$ is a weighting function indicating the weight to be placed on two couples with similar incomes for evaluating violations of couples equity. (If the couples do not have similar incomes, the deviation in taxes between them may not be problematic from the perspective of a desire for couples equity.)

Choosing $T\left(I_{j}\right)$ for all $j$ to minimize this loss function yields similar, albeit more complicated, first-order conditions to the two-couple example examined above. The optimal taxation of marriage will be a "compromise" that reflects the conflicting desires to have marriage neutrality and couples equity. Both principles will be violated to some degree, assuming a desire for progressive income taxes. 
